PIOTR MIODUNKA

Uniwersytet Ekonomiczny w Krakowie

\title{
ELITY W MAŁYCH MIASTACH PRYWATNYCH MAŁOPOLSKI W XVII I XVIII WIEKU
}

Zarys treści: W artykule zostało podjęte zagadnienie elit mieszczańskich w małych miastach Małopolski w okresie nowożytnym. Szczególną uwagę skupiono na osobach piastujących najwyższe urzędy miejskie: radnych i wójtów sądowych oraz na różnicach ustrojowych między miastami prywatnymi a królewskimi. Przejawiały się one m.in. w odmiennej hierarchii urzędów i większej rotacji urzędników. Omówiono też kwestie statusu prawnego mieszczan w dobrach szlacheckich i małomiasteczkowej elity majątkowej.

The content outline: The paper discusses the issue of burgher elites in small towns in Lesser Poland in the modern period. Special emphasis is placed on the people holding the highest municipal administrative posts: town councillors and judicial vogts, and on the differences between political systems in private and royal towns. These differences manifested, among others, in disparate hierarchies of offices and greater rotation of civil servants. The paper also discusses the issue of the legal status of burghers in noble-owned estates and the small-town financial elite.

Słowa kluczowe: małe miasta, miasta prywatne, elita władzy, elita majątkowa

Keywords: small towns, private towns, power elite, financial elite

\section{Wstęp}

Literatura naukowa dotycząca elit w mniejszych miastach Rzeczypospolitej nie jest obszerna. Ze względu na dostępny materiał źródłowy badania koncentrują się na - niekiedy rozmaicie określanych (elita władzy, grupa kierownicza) - osobach piastujących urzędy miejskie. W tym zakresie można jednak mówić o elitarności formalnej (szerokiej) bądź 
materialnej, uzupełnianej o inne aspekty (kwalifikacje) ${ }^{1}$. Pojęcie elity wydaje się jednak bardzo przydatne $\mathrm{z}$ racji swojej wielofunkcyjności możemy mówić o elitarności w różnych kontekstach: władzy, majątku, wykształcenia. W niniejszych rozważaniach zajmę się tylko wybranymi - władzą i w pewnym stopniu majątkiem - i to nie tylko z racji ograniczeń źródłowych, ale także z uwagi na prawdopodobnie wysokie usytuowanie tych „atrybutów” w hierarchii małomiasteczkowego prestiżu. Dostępne źródła stwarzaja przede wszystkim możliwości wskazania i opisania elity władzy. Dużo bardziej skomplikowanym zadaniem jest ukazanie elity majątkowej, a w końcu zakresu powiązania obu grup. Określenie elita władzy funkcjonuje od pewnego czasu w nauce historycznej, własnych opracowań na jej temat doczekały się także miasta ${ }^{2}$. Elita z natury rzeczy nie może być liczna, zatem związana z władza w małych miastach mogła obejmować wyłącznie osoby pełniace najwyższe urzędy. Istotne jest więc, które z nich należy za takie uznać, jaka była ich liczebność oraz sposób powoływania.

Za miasta prywatne tradycyjnie uznaje się lokacje w dobrach szlacheckich i kościelnych ${ }^{3}$. Z biegiem czasu ta kategoria własnościowa stała się dominująca w ramach staropolskiej urbanizacji, w samej Małopolsce miasta prywatne stanowiły w końcu XVII w. około 68\%4. Trzeba jednak przytoczyć opinię Andrzeja Wyrobisza, że w dziedzinie prawnoustrojowej miasta prywatne w Polsce nie wytworzyły specyficznych, sobie tylko właściwych form. Pewien niedorozwój samorządu miejskiego w małych miastach prywatnych wynikał z ich ogólnej słabości ${ }^{5}$. Problematyka podjęta w niniejszym artykule została oparta na opracowaniach drukowanych oraz źródłach rękopiśmiennych odnoszących się do szlacheckich miast południowej, zawiślańskiej części Małopolski. Punktem odniesienia sa ponadto przykłady z mniejszych miast królewskich na tym właśnie obszarze.

${ }^{1}$ M. Kordas, Z badań nad elitami małomiasteczkowymi w Polsce XV-XVI wieku (Rajcy $i$ tawnicy miasta Kamionki $w$ ziemi lubelskiej), „Średniowiecze Polskie i Powszechne" 3 (7), 2011, s. 225.

2 A. Mączak, Rzadzacy i rzadzeni. Władza $i$ społeczeństwo $w$ Europie wczesnonowożytnej, Warszawa 1986, s. 151-153; Z. Noga, Krakowska rada miejska w XVI wieku. Studium o elicie władzy, Kraków 2003, s. 5-8 (tu także wskazanie odpowiedniej literatury).

${ }^{3}$ W nielicznych przypadkach (Kock, Tarnogród, Tykocin) istniejące miasto przechodziło z rąk królewskich w prywatne.

${ }^{4}$ A. Wyrobisz, Rola miast prywatnych $w$ Polsce $w$ XVI $i$ XVII wieku, PH, t. 65, 1974, z. 1, s. 23.

5 Tamże, s. 31. 


\section{Elitarność w małym mieście nowożytnym}

W obecnych czasach odchodzi się już od określenia 'patrycjat', tradycyjnie używanego $\mathrm{w}$ odniesieniu do najbogatszych, zasiedziałych rodzin mieszczańskich, monopolizujących władzę w mieście, jego gospodarkę i czerpiących $\mathrm{z}$ tego tytułu dodatkowe korzyści majątkowe ${ }^{6}$. Zreszta badacze zanegowali istnienie patrycjatu $\mathrm{w}$ małych miastach ze względu na zbyt małe zróżnicowanie zamożności tamtejszych obywateli ${ }^{7}$. Trudno jednak założyć, że były to społeczności całkowicie egalitarne, tak majątkowo, jak i prestiżowo, a zatem można podjąć próbę wyodrębnienia wśród nich grupy o największym znaczeniu, która nazwiemy elita. To określenie jest uniwersalne i nie jest tak bardzo, jak patrycjat, kojarzone z wielkimi ośrodkami miejskimi. Na istnienie elity nawet $\mathrm{w}$ mniejszych ośrodkach wskazują chociażby, analizowane przez Andrzeja Wyczańskiego, taryfy pogłównego z lat 1520 i 1590. Jak podkreśla autor, taryfy odzwierciedlały nie tyle zamożność płatników, ile ich miejsce w hierarchii społecznej (połączenie prestiżu i poziomu dochodów) ${ }^{8}$. Wnioski płynące $z$ analizy taryf pogłównego sa jednoznaczne - nawet $\mathrm{w}$ najsłabiej rozwiniętych ośrodkach można wyodrębnić miejscową elitę, przyjmując za kryterium pełnienie urzędów i zamożność. Pewien kłopot sprawia precyzyjne określenie, które godności lub jaki stopień zamożności pozwalają uznać kogoś za członka ścisłej lokalnej elity. W przypadku elity władzy z cała pewnościa zaliczyć trzeba do niej rajców, bardziej problematycznie rysuje się status wójtów (czy ściślej wójtów sądowych), najbardziej zaś pojemna interpretacja taryf pozwalałaby do elity zaliczyć nawet ławników. Co do kryterium bogactwa przytoczone stawki wskazuja na kupców, ewentualnie szynkarzy. Z rozważań można w zasadzie wyjać młynarzy, w mniejszych ośrodkach młyny należały bowiem bądź do miasta, bądź do właściciela dóbr, a pracujacy w nich pozostawali raczej na uboczu społeczności miejskiej.

Z racji wspomnianych już ograniczeń źródłowych analizie zostaną poddane przede wszystkim mechanizmy funkcjonowania najważniej-

${ }^{6}$ A. Maczak, dz. cyt., s. 182, 188-195; R. Czaja, Spoteczna mobilność jako paradygmat badań nad patrycjatem i grupami kierowniczymi w średniowieczu, w: Elita władzy miasta Krakowa i jej zwiąki z miastami Europy w średniowieczu i epoce nowożytnej (do połowy XVII wieku). Zbiór studiów, red. Z Noga, Kraków 2011, s. 9-21.

${ }^{7}$ M. Bogucka, Miasto - społeczność, w: Encyklopedia historii gospodarczej Polski do 1945 roku, t. 1, red. A. Mączak, Warszawa 1981, s. 524.

8 A. Wyczański, Uwarstwienie społeczne w Polsce $w$ XVI wieku. Studia, Wrocław 1977, s. 201. 
szych instytucji władzy w małych miastach. Podobnie jak w ośrodkach średnich i dużych formalnie najwyższym miejskim ciałem była rada urzędująca (rezydujaca). Wszyscy członkowie rady posiadali jednakowy status, nie istniał bowiem w omawianych miastach odrębny, wyżej usytuowany, urząd burmistrza. Źródła w sposób jednoznaczny wskazują że obowiązki polegające na bieżącym administrowaniu czyli właśnie burmistrza (w XVIII w. często zwanego prezydentem) - były sprawowane przez wszystkich rajców, rotacyjnie przez określona część roku9 . Zmieniała się również nazwa funkcji pozostałych członków rady - w XVI i XVII w. używano słowa rajca, w kolejnym stuleciu określano ich jako radców, a pod koniec tegoż wieku jako radnych ${ }^{10}$. Ustępujący członkowie rady, jeżeli nie zostali ponownie wybrani, uzupełniali grono innych byłych rajców, tworząc tzw. starą radę. Było to ciało o charakterze przede wszystkim doradczym ${ }^{11}$, ewentualnie kontrolnym, a spośród grona byłych rajców rekrutowali się np. mediatorzy negocjujący ugody między mieszczanami ${ }^{12}$. W ten sposób petryfikowano zwiazki oparte na wspólnie sprawowanej władzy i stabilizowano skład elity, uniezależniając go od zmiennych zazwyczaj corocznie kadencji. Do grona najwyższych urzędników należy zaliczyć także landwójta (inne określenia: lantwójt, wójt sądowy, viceadvocatus), którego pozycja była wyższa niż na to wskazują taryfy pogłównego z XVI w. Świadczy o tym nie tylko wyróżniająca tytulatura używana $\mathrm{w}$ stosunku do piastujących te funkcje. Formalnie była to jedynie osoba działajacca w miejsce wójta dziedzicznego w zakresie sądownictwa. W rzeczywistości jego rola była większa. $\mathrm{Z}$ racji substytucyjnej pozycji mianowanie landwójta leżało wyłącznie w gestii starostów bądź dziedziców występujących w tym czasie w roli dziedzicznych wójtów. Ci bynajmniej nie musieli brać pod uwagę pozycji swojego faworyta w społeczności miejskiej i sa przykłady, że pewne osoby na funkcji landwójta nie cieszyły się poważaniem dużej

${ }^{9} \mathrm{O}$ rotacyjnym przekazywaniu godności burmistrza wiadomo m.in. z Krosna i Przeworska; F. Leśniak, Krosno w czasach Odrodzenia. Studia nad społeczeństwem miasta, Kraków 1992, s. 20; M. Horn, Sktad zawodowy magistratu przeworskiego latach 1600-1650 na tle struktury zawodowej i społecznej miasta, PH, t. 60, 1969, z. 2, s. 282, 283. Niemal identycznie wyglądało w XVIII w. nazewnictwo i sposób działania rady w miastach królewskich na Lubelszczyźnie; W. Ćwik, Miasta królewskie Lubelszczyzny w drugiej połowie XVIII wieku, Lublin 1968, s. 77.

${ }^{10}$ Można jeszcze dodać, że pod koniec XVIII w. członkowie rady są nazywani burmistrzami (wtedy jeden $\mathrm{z}$ nich jest prezydentem).

${ }^{11}$ W królewskim Pilźnie w $1654 \mathrm{r}$. z powodu nieobecności starych rajców nie podjęto uchwał podatkowych. Rok później starzy rajcy zaprotestowali przeciwko zbyt wysokiemu opodatkowaniu ról; ANK, rkps dep. 113A, s. 332, 333, 367.

${ }^{12}$ Na przykład w Pilźnie w 1651 r.; ANK, rkps dep. 125, s. 265, 267. 
części mieszczan ${ }^{13}$. O prestiżowej randze landwójtów może świadczyć okoliczność, czy i w jakiej sekwencji pełnili oni funkcje rajców. We wszystkich analizowanych miastach miały miejsce przypadki sprawowania przez te same osoby obu urzędów. W wielu wypadkach najpierw były one rajcami, a dopiero później wójtami sądowymi. Było tak zarówno na początku XVII, jak i pod koniec XVIII w. ${ }^{14}$

Organem sądowym i pomocniczym w stosunku do landwójta była ława, składajaca się we wszystkich omawianych miastach $\mathrm{z}$ siedmiu ławników (ławicznych). Liczebność tego gremium, sposób wyboru, z decydujacym zwykle udziałem landwójta i rady, mniej dostojna tytulatura, przesądzają o tym, by zasiadających w jej składzie nie zaliczać do elity władzy ${ }^{15}$. Interesujaca jest natomiast rola ławy jako swoistej kuźni kadr na wyższe urzędy, a zwłaszcza zwrócenie uwagi na pierwszego z ławników, zwanego starszym (senior) lub podwójcim ${ }^{16}$.

Wyłaniająca się ze źródeł hierarchia awansów - począwszy od ławy, przez radę po urząd landwójta - była praktykowana również w miastach prywatnych. Mówi o tym wprost opis elekcji z 1789 r. w Radomyślu (dziś Radomyśl Wielki) ${ }^{17}$. Tym samym modelowa ścieżka kariery prowadziła tylko w górę, a uzyskanie, chociażby na rok, statusu rajcy oznaczało wejście na trwałe do elity władzy nie tylko za sprawą

${ }^{13}$ Przykład Stanisława Stopkowicza alias Pankracego w królewskim Wojniczu; ANK, Castrensia Sandecensia, rkps 128, s. 1263, 1264, 1573.

${ }_{14}$ Podobną sytuację zaobserwował w małych miastach już w XV w. H. Samsonowicz, Elita władzy w małych miastach Polski w późnym średniowieczu, w: Genealogia - kregi zawodowe i grupy interesu w Polsce średniowiecznej na tle porównawczym, red. J. Wroniszewski, Toruń 1989, s. 148.

${ }^{15}$ Inaczej postapił H. Samsonowicz, dz. cyt., s. 147, a w ślad za nim A. Bartoszewicz, Warta. Społeczeństwo miasta $w$ II połowie XV i na poczatku XVI wieku, Warszawa [1997], s. 131, która wzięła pod uwagę pomocniczo także np. udział w sądach polubownych czy funkcje świadków i egzekutorów testamentów.

${ }^{16} \mathrm{~W}$ królewskim Pilźnie stosowano określenie senior; w prywatnym Przecławiu w 1650 r. obok wójta sądowego (advocatus) występował podwójci (viceadvocatus), który był pierwszym z wymienianych ławników, podobnie było np. w 1734, 1747, 1763, 1776, 1786 r. Natomiast w królewskim Wojniczu początkowo pierwszy z ławników był nazywany seniorem, w 1654 r. został nazwany podwójcim i tak też było w XVIII w. (wtedy łacińskie viceadvocatus było odpowiednikiem polskiego landwójt); ANK, rkps dep. 174, s. 250 ; rkps dep. 176 , s. 144 ; rkps dep. 177 , s. 120 ; rkps dep. 180 , s. 5 ; rkps dep. 182, s. 252 ; rkps dep. 448, s. 260, 261; rkps dep. 450, s. 29, 47, 88, 162, 163; Księgi miejskie wojnickie, t. 1: Advocatialia 1575-1627, oprac. J. Szymański, Wojnicz 1995, nr 694.

17 „Po naradzeniu się wspólnym, pospólstwo miasta Radomyśla nieporządnie kandydatów podające, bo nie gradualnie, podług praw i wyroków krajowych, kiedy na wójta bez praktycznego urzędu burmistrzowskiego, na burmistrza bez poprzedzającej usługi ławniczowskiej, kandydatów popisało...”; Центральний державний історичний архів України, м. Львів (dalej: ЦДІАУЛ), f. 40, op. 1, spr. 10, s. 223. 
łatwiejszego ponownego objęcia tej funkcji (doświadczenie) czy też możliwości „postapienia” na landwójtostwo (tam gdzie było to ukoronowaniem kariery), ale głównie ze względu na tytuł starego rajcy (rajcy przeszłych rezydencji), który przysługiwał dożywotnio.

Interesująca jest kwestia, na ile elita władzy pokrywała się z elita majątkowa, czy wszyscy rajcy dysponowali dużym majątkiem, czy sprawowanie najwyższych urzędów sprzyjało pomnażaniu dochodów, czy byli tacy mieszczanie, którzy mimo zamożności nie osiąnęli wyższych urzędów miejskich. Trudno określić jednoznacznie kryteria pozwalające uznać daną osobę za zamożna. Wydaje się, że mogą o tym przesądzać takie okoliczności jak: posiadanie domu w rynku (zwłaszcza kamienicy) lub kilku domów w mieście, posiadanie folwarków, większej powierzchni gruntów, browarów i gorzelni, wykonywanie niektórych zawodów (kupcy, kuśnierze), obracanie większymi sumami w gotówce.

\section{Miasta prywatne a miasta królewskie}

\section{Ewolucja ustroju miast}

Ustrój miast południowej Polski, majacy fundament w prawie magdeburskim, nie pozostał obojętny na wpływ ogólnopaństwowych przemian inspirowanych w XVI w. m.in. przez szeroki ruch szlachecki. Na wzór nazwy całego państwa - Rzeczpospolita - gminy miejskie także określały się jako rzeczypospolite ${ }^{18}$. Bardzo wyraźnie obserwujemy to w źródłach pochodzących z małych miast królewskich ${ }^{19}$. Pytanie, czy taka recepcja nastapiła także $\mathrm{w}$ miastach prywatnych, przez absolutne podporządkowanie władzy dziedzica tylko pośrednio związanych z całościa państwa? Sytuacja w Nowym Wiśniczu nie odbiegała od

18 J. Motylewicz, Społeczeństwo Przemyśla w XVI i XVII wieku, Rzeszów 2005, s. 111.

${ }^{19}$ W 1588 r. mowa jest o Rzeczypospolitej Pilzneńskiej i pojęcie to występuje już regularnie do I rozbioru, np. w $1613 \mathrm{r}$. miał zostać znieważony cech tkacki oraz „cała Rzeczypospolita”. Najbardziej rozbudowane określenie brzmiało - Rzeczpospolita miasta Pilzna Króla Jego Mości. Spotykamy wręcz nawiązywanie do republikańskich tradycji antycznych, kiedy mieszczanie zwołani na elekcję władz w 1604 r. zostali określeni jako senatus populusque pilsnensis; ANK, rkps dep. 109, s. 389, 725; rkps dep. 118, s. 221; rkps dep. 113, s. 266; inne przykłady: ANK, rkps dep. 113, s. 160; rkps dep. 113A, s. 45-47, 249; rkps dep. 114, s. 2; rkps dep. 124, s. 25; rkps dep. 283, s. 120; rkps dep. 285, s. 63. W Wojniczu w 1577 r. mowa o kasie miejskiej Wojnicza jako o skarbie Rzeczypospolitej, a w 1619 r. o Rzeczypospolitej Wojnickiej; Lauda miasta Wojnicza, wyd. J. Szymański, Wojnicz 1994, s. 11, 27, 31, 33, 41, 52; ANK, rkps dep. 172 , s. $151,154,231$; rkps dep. 174 , s. $34,86$. 
zarejestrowanej w ośrodkach królewskich: w latach 40. XVII stulecia rada miasta toczyła tam spór z „Rzeczypospolitą miejska”, a uchwała rady wiśnickiej określona została jako Senatus consultum ${ }^{20}$. Również przykłady z Przecławia wskazuja na podobne analogie - w 1671 r. zapadła uchwała „rzeczypospolitej” w sprawie nowego sposobu repartycji podatków między mieszczan, a w 1678 r. landwójta obrażono stwierdzeniem, że jest „zdrajca Rzeczypospolitej”"21. Również w innym prywatnym mieście - Radomyślu - spotykamy to określenie ${ }^{22}$.

Formalna równość wszystkich mieszczan w praktyce objawiała się w dużym znaczeniu zgromadzenia pospólstwa jako organu kontrolnego i uchwałodawczego. Z zachowanych materiałów wynika, że to pospólstwo stanowiło lokalne przepisy (lauda, uchwały), decydowało o obciażeniach finansowych mieszkańców, podejmowało indywidualne decyzje, dokonywało wyboru niektórych urzędników miejskich ${ }^{23}$. Wydaje się, że $\mathrm{w}$ tej kwestii nie było zasadniczych różnic między miastami królewskimi a prywatnymi. Zachowały się przekazy o zebraniach pospólstwa (schadzkach) np. z Limanowej, Nowego Wiśnicza, Przecławia czy Zakliczyna ${ }^{24}$.

Franciszek Leśniak omawiając stosunki ustrojowe nowożytnej Limanowej, posuną się do stwierdzenia, że w tym mieście rada funkcjonowała w zasadzie tylko w XVI w., a później jeżeli w ogóle (pozostały dwa ślady jej istnienia w XVII i XVIII w.) to zupełnie zmarginalizowana przez urząd wójta sądowego i podwójciego ${ }^{25}$. Faktem jest, że $\mathrm{np}$. w 1663 r. zeznanie w sprawie poboru czopowego, a zatem typowej kompetencji rady miejskiej, złożyli w grodzie sądeckim limanowski wójt sądowy z ławnikiem, stwierdzając wprost: „,czopowe w miasteczku naszym urząd wójtowski na ten czas na sobie ponosząc...”. W tym czasie na kartach tej samej księgi relacji grodu sądeckiego pojawiają się informacje o radzie bądź radnych z innych niedużych sasiednich miast

${ }^{20}$ ANK, rkps IT 2046, s. $62,76$.

${ }^{21}$ ANK, rkps dep. 463, s. 14, 124.

${ }^{22}$ ЦДІАУЛ, f. 40, op. 1, spr. 7, k. 16 (1669 r.).

23 Podobną pozycję miało pospólstwo w Wadowicach (do 1727), możliwe, że tak duża rola pospólstwa jako całości była charakterystyczna dla małych miast; J. Ptaśnik, Miasta i mieszczaństwo $w$ dawnej Polsce, Warszawa 1949, s. 106. W wielu nieco większych miastach ziem przemyskiej i sanockiej rolę reprezentacji pospólstwa przejmowało kolegium cechmistrzów; J. Motylewicz, Miasta ziemi przemyskiej $i$ sanockiej $w$ drugiej połowie XVII i XVIII wieku, Przemyśl 1993, s. 96.

${ }^{24}$ Limanowa: F. Leśniak, Miasto w latach 1565-1772, w: Limanowa. Dzieje miasta, t. 1, red. F. Kiryk, Kraków 1999, s. 91, 92; Nowy Wiśnicz: ANK, rkps dep. 160, s. 191; Przecław: ogół mieszczan podejmował uchwały w sprawie repartycji obciążeń podatkowych, brał udział w elekcji rady; ANK, rkps dep. 452, s. 4, 27, 83; 463, s. 14. W Zakliczynie zachowana księga miejska mówi o udziale pospólstwa w wyborze części urzędników.

${ }^{25}$ F. Leśniak, Miasto..., s. 87-90. 
szlacheckich bądź kościelnych: Bobowej, Brzeska, Muszyny, Tuchowa i Zakliczyna ${ }^{26}$. Zaniknięcie urzędu radzieckiego wydaje się na tyle nietypowe, że potwierdzenie tej hipotezy wymaga dalszych badań.

Zasadniczą różnica, rzutująca także na funkcjonowanie urzędów miejskich i tym samym zapewne na sposób kreowania elit, był sposób zarządzania przez zwierzchność. W przypadku małych miast królewskich można mieć niekiedy przekonanie, że nie miały one gospodarza. Jeśli starostom nie udało się zupełnie ich sobie podporządkować, to traktowano je jako byt niemalże zewnętrzny, służący jedynie do wyegzekwowania należnych opłat. Dopiero panowanie Stanisława Augusta Poniatowskiego zwiastowało pewną zmianę, związaną z większym zainteresowaniem władzy centralnej. Natomiast miasta prywatne popadły w sytuację skrajnie odmienną. Ilość ordynacji wydawana przez właścicieli wydaje się przytłaczająca, prowadząc niemalże do zastapienia normatywnej działalności rady miejskiej ${ }^{27}$. Niemniej jednak dzięki tej nadaktywności i paternalistycznej trosce to miasta prywatne szybciej podnosiły się po klęskach z początku XVIII w.

Podsumowujac, w zakresie ewolucji urzędów miejskich miast prywatnych można zwrócić uwagę na zapewne wyższą pozycję wójta sądowego kosztem rady miejskiej i być może zanik funkcjonowania starej rady. Trzeba jednak wziąć pod uwagę, że sytuacja mogła być w dużym stopniu uzależniona od wielkości i rangi ekonomicznej ośrodka.

\section{Pozycja prawna mieszczan w dobrach prywatnych}

Omawiajac problem elit małych miast prywatnych, nie sposób nie poruszyć kwestii wolności osobistej mieszczan w tej kategorii ośrodków. Badacze tego zagadnienia skłaniają się do twierdzenia, że formalnie, zgodnie z prawem publicznym, mieszczanie wszystkich miast byli osobiście wolni. Zaobserwowali jednak, że w prywatnych dobrach w stosunku do mieszczan nawet znaczniejszych miast zdarzały się praktyki rażącego naruszania tej zasady ${ }^{28}$.

${ }^{26}$ ANK, Castrensia Sandecensia Relationes, rkps 129, s. 4, 202, 231, 253, 711, 1634.

${ }^{27}$ Było to zjawisko powszechne w całej Koronie; por.: D. Mazek, Ku ozdobie i profitowi. Prawodawstwo miast prywatnych Wielkopolski 1660-1764, Warszawa 2003, s. 199; A. Średzińska, Pozycja mieszczan w miastach prywatnych ziemi drohickiej $i$ mielnickiej $w$ XVI-XVIII wieku, w: Miasta polskie $w$ średniowieczu i czasach nowożytnych, red. P. Gołdyn, Kraków 2008, s. 283, 296, 297.

${ }_{28}$ M. Bogucka, H. Samsonowicz, Dzieje miast $i$ mieszczaństwa $w$ Polsce przedrozbiorowej, Wrocław 1986, s. 393-401; T. Opas, Z badań nad zagadnieniem wolności osobistej mieszczan miast prywatnych w Polsce XVII i XVIII wieku, CPH, t. 35, 1983, 
Różnice w statusie mieszkańców miast nienależących do dóbr państwowych (królewskich) znalazły w źródłach odbicie w odmiennych znaczeniach nadawanych pojęciu „poddany”. Status poddanego królewskiego nie uwłaczał ${ }^{29}$. Wobec mieszczan z miast prywatnych używano tego określenia w pogardliwym kontekście. Nawet były lantwójt i radca królewskiego Pilzna Tomasz Woliński usłyszał od swojego szwagra: „ty poddańczuchu, do Łańcuta się rządzić, a nie tu” ${ }^{30}$. W 1779 r. przed sądem pilzneńskim pozwani kwestionowali pełnomocnictwo drugiej strony, złożone przez Żydówkę z Tarnowa, „ile z dóbr ziemskich pochodząca bez przytomności i zwierzchności albo wiedzenia dworu uczyniła w aktach niniejszych plenipotencję, przeto sądu jeszcze niniejszego o rozeznanie tej uczynionej o ważność albo nieważność...”. Sąd nie uznał, że w tej sprawie mieszkańcy prywatnego miasta mają ograniczoną zdolność do czynności prawnych ${ }^{31}$. Takie sytuacje brały się jednak najwyraźniej z obserwacji rzeczywistości.

Jednym ze składników wolności osobistej jest prawo do swobodnej zmiany miejsca zamieszkania. Jest sporo przekazów, które świadcza, że od mieszczan z dóbr ziemskich wymagano zwolnienia z poddaństwa, aby mogli oni przeprowadzić się do innego miasta. Już w 1584 r. Benedykt Stelmach z miasteczka Rzochowa, w majątku Tarnowskich, nie mógł się przenieść do pobliskiego Mielca, bo zabronił mu tego dziedzic $^{32}$. W XVII w. w wyniku głębokiego kryzysu gospodarczego zjawisko to się nasiliło. Nawet w tak znacznym mieście jak Tarnów jego właściciel w 1648 r. zakazywał mieszczanom samowolnego jego opuszczania na stałe pod karą konfiskaty mienia ${ }^{33}$. W 1665 r. Kasper Brzechwa,

z. 1, s. 59-93; tenże, Z badań nad zagadnieniem umacniania się zasady wolności osobistej mieszczan miast prywatnych w Polsce XVIII wieku, w: Ustrój i prawo w przeszłości dalszej i bliższej. Studia historyczne o prawie dedykowane prof. Stanistawowi Grodziskiemu w pięćdziesiata rocznice pracy naukowej, red. J. Malec, W. Uruszczak, Kraków 2001, s. 146, 148, 149. Naruszenia wolności osobistej polegały głównie na zakazach wyprowadzania się z miasta, a nawet oddalania na dłużej, czy też na kontrolowaniu obrotu nieruchomościami mieszczan; A. Codello, Zbiegostwo mieszczan rzeszowskich w pierwszej połowie XVIII w., „Małopolskie Studia Historyczne” 1, 1958, z. 1, s. 17, 18.

${ }^{29}$ Tak np. mieszczanie wojniccy nazywali samych siebiepoddanymi Jego Królewskiej Mości, a chłopów z pobliskiego Zamościa poddanymi starosty; ANK, rkps dep. 179B, s. 21, 65,

${ }^{30}$ ANK, rkps dep. 285, s. 112.

${ }^{31}$ ANK, rkps dep. 115, s. 202-212.

${ }^{32}$ ANK, rkps dep. 443, s. 297 (Stelmach umówił się już na kupno domu w Mielcu, a nawet zapłacił zadatek).

${ }^{33}$ S. Wróbel, Tarnów $w$ XVII i XVIII w., w: Tarnów. Dzieje miasta i regionu, t. 1: Czasy przedrozbiorowe, red. F. Kiryk, Z. Ruta, Tarnów 1981, s. 335 (list Władysława Dominika Ostrogskiego). 
właściciel miasta Limanowa, domagał się od magistratu wojnickiego wydania zbiegłego poddanego Krzysztofa Jeżowica, szewca, do czego jednak nie doszło ${ }^{34}$. Żadnej watpliwości nie pozostawiaja przekazy z Przecławia. W 1668 r. czterech tamtejszych mieszczan poręczyło za Kazimierza Winiarskiego, który pojmując za żonę miejscowa pannę Przybyłównę, zobowiązał się „z poddaństwa Jmci nie wychodzić, ale z żona swoja $\mathrm{w}$ poddaństwie Jmci zostawać i dom w mieście budować”. Podobnie w 1746 r. trzech mieszczan ręczyło, że młody Wojciech Typerkowicz, który udał się na wędrówkę „według zwyczajów w rzemiesłach”, wróci do Przecławia, do swojego mistrza „i będzie zostawał w poddaństwie...” ${ }^{35}$. Zachował się, oblatowany w grodzie bieckim w 1675 r., dokument wyzwolenia z poddaństwa wystawiony w 1650 r.: „Stanisław Koniecpolski [...] wiadomo czynię [...], że ja respectując na życzliwe usługi sławetnego Jana Pałyszewicza, mieszczanina mego i rayce przecławskiego [...] uwalniam tym pisaniem moim uczciwego Jana Pałyszewicza, syna jego, z poddaństwa mego czasy wiecznymi dając mu wszelaką wolność gdziekolwiek by chciał mieszkać kupczyć i według upodobania swego życie swe przystojnie..."36.

Ten stan nie zmienił się do końca XVIII w., w 1781 r. bowiem urząd pilzneński zawiesił obywatelstwo Stanisława Artwińskiego przybyłego z Radomyśla, miasta Wodzickich, który je przyjął „nie mając uwolnienia od Pana swego, pod którym dawniej zostawał" 37 .

Poddaństwo mieszczan z miast prywatnych nie stawiało ich jednak w takiej samej sytuacji jak poddanych chłopów. Kolejni dziedzice Przecławia potwierdzali w latach 1664, 1678, 1684 swoim mieszczanom przywileje zawierające zakaz pociagania ich do nadzwyczajnych posług czy gwarantujace swobodne dysponowanie placami i budynkami, chociaż brak w nich wyraźnego odniesienia do swobód osobistych ${ }^{38}$. Wydaje się, że szlacheccy właściciele generalnie nie kwestionowali przywilejów miast, nie domagali się świadczeń innych niż takie, jakie były właściwe ośrodkom miejskim. Zależało im, aby ich poddani zajmowali się rzemiosłem i handlem, a w ramach wykonywanych zajęć przemieszczali się swobodnie, chodziło jednak o to, by kontrolować przepływ migracji, środkami administracyjnymi zabiegać wyludnieniu miasta. Nie wiemy ponadto dokładnie, na ile ograniczanie swobody zmiany miejsca zamieszkania było powszechna praktyka, a na ile wynikało z bliższego

${ }^{34}$ ANK, Castrensia Sandecensia, rkps 130, s. 107; tamże, rkps IT 284b, s. 429, 433.

35 ANK, rkps dep. 448, s. 308; rkps dep. 451, s. 12.

36 ANK, Castrensia Biecensia, rkps 198, s. 943, 944.

37 ANK, rkps dep. 291, s. 3.

${ }^{38}$ ANK, rkps dep. 458, nr 5, 7, 8. 
zainteresowania tą sprawą niektórych tylko właścicieli. W księgach przecławskich w XVII w. niemal brak np. śladów kontroli dziedziców nad obrotem nieruchomościami miejskimi, jednostkowy przypadek z 1642 r., kiedy transakcja sprzedaży przez mieszczanina Jana Pałysa domu ze słodownią nastapiła za wyraźna zgoda dziedziczki, wynikał zapewne z faktu, że nabywca był szlachcicem ${ }^{39}$. W 1733 r. dziedzic Jan Rej, z niewiadomych pobudek, zaingerował w swobodę obrotu, kasując wpisana już transakcję sprzedaży domu, pozwalając na jego sprzedaż, ale komuś innemu ${ }^{40}$. Natomiast w drugiej połowie XVIII w. wiele transakcji między mieszczanami opatrzonych jest zgodą aktualnych właścicieli dóbr, poświadczoną własnoręcznymi podpisami ${ }^{41}$. Nie da się zaprzeczyć, że mieszczanie z dóbr prywatnych cieszyli się - przynajmniej okresowo lub w niektórych sprawach - mniejszym zakresem swobody osobistej od swoich odpowiedników z królewszczyzn. Z drugiej strony, od wiejskich mieszkańców majątków szlacheckich odróżniały ich inne obowiązki i uprawnienia. Różnica między poddanym chłopem a poddanym mieszczaninem $w$ dobrach prywatnych widoczna była chociażby w przypadku popełnienia przestępstwa - obywatelowi z miasta prywatnego przysługiwał „przywilej” odbywania kary w więzieniu miejskim, a nie dworskim ${ }^{42}$. Przypadek Przecławia zdaje się uzupełniać obserwacje poczynione w stosunku do innych obszarów Rzeczypospolitej. Prowadzą one o wniosku, że podporządkowanie miast w każdej dziedzinie prywatnym właścicielom i drobiazgowe niekiedy regulowanie wielu kwestii mocno indywidualizowało sytuację mieszczaństwa wzajemnie między nimi, jak również w każdym z miast w wymiarze czasowym ${ }^{43}$.

Po zajęciu południowej Małopolski przez Austrię władze państwowe zainteresowały się również ludnością miast i wsi w majątkach prywatnych. W 1783 r. pod elekcją nowego magistratu przecławskiego podpisał się komisarz cyrkularny, a w roku następnym na rozkaz tegoż sąd miejski rozpatrywał spór między administratorem dóbr a dawnymi burmistrzami ${ }^{44}$. W takich warunkach szybko postępowała mentalna

${ }^{39}$ ANK, rkps dep. 448, s. 213 (kupił pan Mikołaj Czerniszowski).

${ }^{40}$ ANK, rkps dep. 449, s. 148-149.

${ }^{41}$ Zwłaszcza w latach 1760-1762 Tadeusza i Józefa Rejów, w latach 1768-1774 Elżbiety z Rejów Krasickiej; ANK, rkps dep. 450, s. 1-3, 15, 19, 26, 32.

${ }^{42}$ W 1678 r. w Przecławiu chłop z przedmieścia trafił do więzienia zamkowego, a mieszczanin do więzienia miejskiego; ANK, rkps dep. 463, s. 123.

${ }^{43}$ Przypadki ograniczana swobody przemieszczania czy dysponowania nieruchomościami w prywatnych (szlacheckich i duchownych) miastach terenów sąsiadujacych od wschodu z południową Małopolską omawia J. Motylewicz, Miasta..., s. 57, 61-63, 69, 70.

${ }^{44}$ ANK, rkps dep. 452, s. 4, 34 . 
emancypacja mieszczan przecławskich. W 1785 r. miejscowy ekonom, niejaki Domański, siłą naruszył prawo magistratu do ukarania szlachcica zakłócającego porządek publiczny, wreszcie zranił jednego z mieszczan obuchem. Na sprawcę skarżył się nie tylko osobiście poszkodowany, ale również „my cały magistrat najprzód zelżenia osób i za zgwałcenie jurysdykcyi naszej miejskiej od najwyższych rządów i dziedziców a bardziej od samego Boga [podkr. P.M.] stwórcy naszego nam powierzonych..." 45 .

\section{Zewnętrzne oznaki prestiżu}

Analiza określeń używanych $\mathrm{w}$ stosunku do mieszczan $\mathrm{w}$ małych miastach prowadzi do wniosku, że nie sa to precyzyjne narzędzia i moga być tylko częściowo przydatne przy wydzieleniu elity od pozostałych obywateli. Wyraźna jednak była tendencja do podkreślenia rangi głównych urzędników miejskich. Można też zaobserwować, zauważona już przez Włodzimierza Dworzaczka, dewaluację tytułów - zanik określenia providus, rozpowszechnienie przymiotnika famatus $\mathrm{w}$ drugiej połowie XVIII w.

Broń biała zwykle była oznaka przynależności do klas elitarnych. Nic więc dziwnego, że w rozporządzeniach właścicieli miast prywatnych spotykamy zakazy używania jej przez mieszczan ${ }^{46}$. Z drugiej strony znane sa ordynacje wręcz nakazujące jej posiadanie $z$ uwagi na zewnętrzne niebezpieczeństwo ${ }^{47}$. W praktyce, prawdopodobnie nawet wbrew wszelkim zakazom, również mieszczanie miast prywatnych nie stronili od używania szabel w sytuacjach zupełnie osobistych ${ }^{48}$.

45 Tamże, s. 44, 45.

${ }^{46}$ W Rzeszowie w 1735 r. dziedzic wydał zakaz noszenia szabli, szpady lub kordelasu, chociaż dopuszczalne były pewne wyjątki; A. Codello, dz. cyt., s. 19.

${ }^{47}$ Według rozporządzenia właściciela z 1680 r. w Zakliczynie, ze względu na bezpieczeństwo miasta, każdy mieszczanin miał obowiązek posiadać „strzelbę długa, szablę"; ANK, rkps dep. 424, s. 40. W Mielcu w 1719 r. wydano podobny nakaz i obywatele mieli się zaopatrzyć w „flintę, szablę, ładownicę”; ANK, rkps dep. 444, s. 55.

${ }^{48} \mathrm{~W} 1732$ r. na dwóch mieszczan pilzneńskich napadł z szabla zdeterminowany wierzyciel Gardulski, mieszczanin z prywatnego Radomyśla; mieszczanin przecławski Wojciech Kuśnierz w 1665 r. paradował z szablą u boku na jarmarku w Mielcu; w samym Przecławiu w 1671 r. podczas stypy doszło do bójki, a mieszczanie „popiwszy szabel dobywali”; w Nowym Wiśniczu stary radca Aleksander Michalski porwał się do szabli na aktualnego radcę Jakuba Noskowicza (1724); ANK, rkps dep. 160, s. 264; rkps dep. 283, s. 11; rkps dep. 462, s. 45; rkps dep. 463, s. 26. 


\section{Elita władzy}

$\mathrm{Na}$ formowanie elity władzy niebagatelny wpływ ma podmiot nominujący na najwyższe urzędy. W przypadku wyboru rady istniała w tym względzie spora różnorodność. Spotykamy przykłady stosunkowo dużej samodzielności mieszczan miast prywatnych. W Nowym Wiśniczu połowę składu wskazywała zwierzchność, a połowę pospólstwo. W Zakliczynie w 1602 r. ordynacja mówiła o wyborze trzech rajców przez dwie zwierzchności, a ostatniego miało wskazywać pospólstwo. Przynajmniej od 1689 r. właściciele pozwolił wybierać ogółowi mieszczan dwóch radnych, czyli połowę składu ${ }^{49}$. Dla Przecławia zachowało się tylko klika przekazów o wyborze rady. Według jednego z nich, z 1783 r., pospólstwo wskazało jednego z czterech radnych. Jeśli potraktować dosłownie informację z 1785 r., to wyboru wszystkich urzędników, $\mathrm{w}$ tym radnych, dokonali samodzielnie mieszczanie, chociaż w obecności przedstawiciela dworu ${ }^{50}$. W Mielcu dział majątkowy braci Mieleckich z 1548 r. postanawiał, że po jednym członku rady wskaże każda z trzech zwierzchności, a czwartego pospólstwo. W pierwszej połowie XVIII stulecia rada tego ośrodka liczyła sobie nietypowo, bo nieparzystą liczbę trzech członków, wszystkich wskazywanych przez zwierzchności miasta (właściciel 2/3 nominował dwóch, właściciel 1/3 jednego $)^{51}$. Wójta sądowego zwykle powoływał miejscowy dziedzic, niekiedy jako właściciel wykupionego wójtostwa miejskiego. Niemniej jednak w Łęcznej wskazywali go (także jego zastępcę, czyli pierwszego ławnika zwanego tam landwójtem) sami mieszczanie ${ }^{52}$. W tym mieście najwyższa pozycja wójta sądowego nie ulega wątpliwości. Łęczyńska hierarchia awansu wyglądała następująco: ława, rada, landwójt (podwójci), wójt i nic nie wskazuje na to, aby w XVIII w. miała być

${ }^{49}$ ANK, rkps dep. 424, s. 23, 65.

${ }^{50}$ Liczba rajców także była zmienna: w XVII w. było ich czterech, w pierwszej połowie XVIII w., a zapewne jeszcze w latach 70. - dwóch, a przynajmniej od $1783 \mathrm{r}$. ponownie czterech; ANK, rkps dep. 448, s. 62; rkps dep. 449, s. 150; rkps dep. 450, s. 29; rkps dep. 451, s. 39; rkps dep. 452, s. 4, 27; rkps dep. 463, s. 101.

51 J. Pezda, P. Prokop, Mielec i okolice w połowie XVI wieku, „Rocznik Mielecki” 2, 1999, s. 136; ANK, rkps dep. 444, s. 166 (1728 r.).

${ }^{52}$ Jeszcze w XVI w., po wykupieniu wójtostwa dziedzicznego, mianowanie wójta sądowego leżało w gestii dziedziców; R. Szczygieł, Powstanie miasta Łęcznej i jego rozwój do końca XVI w., w: Łęczna. Studia z dziejów miasta, red. E. Horoch, Łęczna 1989, s. 42. Późniejsze zapisy wskazują w tym zakresie na samodzielną wolę mieszczan; J. Łosowski, Urzędnicy miejscy, cechowi, braccy i szpitalni Łęcznej do r. 1810. Spisy, Łęczna 2004, s. 19, 20. 
naruszana. Dodatkowo wójtowie sądowi sprawowali swoją powinność przez długie lata ${ }^{53}$.

W przypadku niektórych miast prywatnych istnieje jednak poważna wątpliwość co do prestiżowego usytuowania rady miejskiej, zwłaszcza w XVIII w. Można w tym czasie zaobserwować, że mieszczanie przecławscy, radomyscy bądź zakliczyńscy zajmujący stanowisko radnych $\mathrm{w}$ kolejnych latach obejmują funkcje w pobliskich miastach królewskich (Pilzno, Wojnicz), usytuowane z pewnością niżej w hierarchii podwójcich lub nawet szeregowych ławników. Mieszczanin zakliczyński Jan Smagowicz w 1733 r. został radnym, ale w latach 1738-1741 pełnił funkcję pierwszego ławnika. Analogiczna sytuacja miała miejsce w przypadku Michała Kujawskiego, Wojciecha Bartkowskiego, Stanisława Pękalskiego czy Józefa Czerkasa. Co więcej, Bartkowski i Pękalski byli także szeregowymi ławnikami. Najbardziej spektakularny wydaje się jednak przypadek Antoniego Burzewicza, który w 1732 r. był radnym, potem kilkukrotnie obejmował urząd wójta sądowego (1736, 1737, 1740, 1749), aby kończyć karierę w 1752 r. jako ławnik. Przy elekcji zaznaczono jednak, że wymówił się słabymi siłami, zatem w jego miejsce delegowało innego byłego radnego, Jakuba Mikulskiego ${ }^{54}$. W Przecławiu Wojciech Kordziński był w latach 1776 i 1777 pierwszym ławnikiem, czyli podwójcim, w 1779 r. występuje jako burmistrz, aby w 1784 r. zostać zwykłym ławnikiem ${ }^{55}$. Stanisław Sałacki z kolei w 1777 r. był burmistrzem, potem (1779-1781) podwójcim i ławnikiem (1784), wreszcie w 1787 r. objął urząd landwójta ${ }^{56}$. Idzi Niedzielski był dwa razy, naprzemiennie, podwójcim $(1784,1786)$ i radnym $(1785,1787)^{57}$. W przypadku Jana Moszczeńskiego i Jana Zięby kolejność urzędów była następująca: ławnik, radny, podwójci ${ }^{58}$. Analogicznie rzecz wyglądała w pobliskim, także szlacheckim, Radomyślu. Dla drugiej połowy XVIII w. ustalono kilku mieszczan, którzy na zmianę pełnili urzędy ławników, burmistrzów (radnych), podwójciego czy wójta (landwójta). Często karierę kończyli w charakterze podwójcich.

${ }^{53}$ Zarówno Szymon Korol, Antoni Kopeć, Stefan Ciołkiewicz, Andrzej Plechawski, jak i Józef Kopeć, zanim zostali wójtami, uprzednio pełnili funkcje landwójtów (podwójcich), a jeszcze wcześniej radnych; J. Łosowski, dz. cyt., s. 48-89.

${ }^{54}$ ANK, rkps dep. 424, s. 154.

${ }_{55}$ ANK, rkps dep. 450, s. 47, 61, 86; rkps dep. 452, s. 27, 83.

${ }^{56}$ ANK, rkps dep. 450, s. 63, 82, 95, 98, 106; rkps dep. 452, s. 27, 76.

57 ANK, rkps dep. 450, s. 150, 166; rkps dep. 452, s. 27, 83.

${ }_{58}$ Ponadto Bartłomiej Skowroński był w 1778 r. burmistrzem, a w latach 1780 i 1781 ławnikiem; ANK, rkps dep. 450, s. 72, 98, 114, 128, 139, 143, 148, 163; rkps dep. 452 , s. 27,83 . 
Niewykluczone, że ta funkcja, prawdopodobnie obsadzana przez samych mieszczan, uchodziła akurat za bardziej prestiżowa niż w tych miastach, gdzie mieszkańcy mieli większy wpływ na wybór rady ${ }^{59}$.

W Przecławiu, przy zastrzeżeniu dużych luk źródłowych, odnotowano ponadto przypadki landwójtów niebędących uprzednio rajcami. Podobnie było też chyba w Zakliczynie, gdzie np. wielokrotny w latach 1744-1771 wójt Andrzej Styrkowski nie jest uprzednio notowany jako radny. Jego pozycja w elicie władzy była jednak wyjątkowa (dzięki poparciu właściciela?) skoro w 1773 r. nazwano go seniorem miasta i wszyscy urzędnicy mieli zasięgać u niego rady ${ }^{60}$.

Ten pozorny brak logiki wynikał najwyraźniej z przemyślanej polityki administracji dworskich. Jasno to przedstawia zapis elekcji magistratu Radomyśla z 1790 r.: „ponieważ od objęcia funkcji [...] rok skończył się, a ciż dalej na tych urzędach zostawać nie moga, z powodu aby ten ciężar równie wszystkich obywateli dosięgał..." ${ }^{61}$. Problem zmniejszenia atrakcyjności funkcji radnych był zdaje się nieobcy także znaczniejszym ośrodkom. W $1771 \mathrm{r}$. wobec braku chętnych na ten urząd komisarz hrabstwa tarnowskiego zdecydował, że każdy z właścicieli posesji w obrębie murów będzie „prezydował” przez 12 dni w roku ${ }^{62}$. Niemniej jednak w Radomyślu, a zdaje się i w Przecławiu, spotykamy w tym czasie osoby przez dłuższy czas, czasami wręcz bez przerwy, piastujące godność radnego czy landwójta i nieulegajace późniejszej prestiżowej degradacji ${ }^{63}$.

Należy w tym miejscu postawić pytanie, czy wspólny większości polskich miast schemat wyłaniania elity władzy, zakorzeniony w ustroju opartym na prawie magdeburskim, w niektórych ośrodkach po pewnym

${ }^{59}$ Przykłady „nieliniowych” karier mieszczan radomyskich: Andrzej Rogalski burmistrz (1758), lawnik (1759), burmistrz (1760, 1761); Antoni Krupski - burmistrz (1765), ławnik (1772, 1773), burmistrz (1774-1776), podwójci (1781, 1783); Klemens Domański - wójt $(1757,1759)$, podwójci $(1762,1765)$, burmistrz (1767), podwójci (1763, 1764); Piotr Wolakowski - ławnik (1778), wójt (1779), burmistrz (1781, 1783), podwójci (1789); ЦДІАУЛ, f. 40, op. 1, spr. 10, s. 215, 225, 394-400, 405-408, 410, 411, 413, 416. Obejmowanie przez byłych rajców funkcji ławników zaobserwowano już w pierwszej połowie XVII w. w szlacheckim (średniej wielkości) Przeworsku; M. Horn, dz. cyt., s. 284.

60 ANK, rkps dep 424, s. 183.

61 ЦДІАУЛ, f. 40, op. 1, spr. 10, s. 225.

62 S. Wróbel, dz. cyt., s. 337.

${ }^{63}$ W Radomyślu Błażej Stoczkiewicz był burmistrzem w 1765 i 1771-1776, a w 1766 r. wójtem sądowym, Kazimierz Bal był burmistrzem w latach 1762, 1763, 1772, 1773, 1777-1780; ЦДІАУЛ, f. 40, op. 1, spr. 10, s. 398-401, 404-412. W Przecławiu Andrzej Szeglowski w 1776 r. występuje jako burmistrz, a następnie w latach 1777-1781 i 1783 landwójt; ANK, rkps dep. 450, s. 48, 63, 70, 82, 98, 106, 128. Należy jednak zastrzec, że z obu tych miast nie są znane pełne składy wszystkich urzędów w drugiej połowie XVIII w. 
czasie nie uległ daleko idącym modyfikacjom? Na podstawie częściowej rekonstrukcji karier kilku osób, dokonanej na podstawie ksiag miejskich z Przecławia z drugiej połowy XVII w., można ostrożnie postawić tezę, że model kariery urzędniczej, hierarchia prestiżu funkcji miejskich i wyłanianie elity władzy przebiegały wówczas jeszcze według tradycyjnego schematu, w miastach królewskich zachowanego do końca okresu staropolskiego. Wsparciem dla tej tezy jest ponadto poświadczenie występowania byłych członków rady z tytułem „starych” rajców i bezpośrednie funkcjonowanie starej rady jako gremium (1678) ${ }^{64}$. Tytuł starego rajcy spotykamy u mieszczan przecławskich jeszcze w $1736 \mathrm{r}$. Jego późniejszy zanik nie wydaje się być jedynie efektem braków źródłowych. Złamanie zasady awansowania tylko w jedną stronę, czyli pełnienie przez byłych radnych ponownie funkcji sądowniczych w ławie, automatycznie podcinało byt starej rady jako osobnego ciała. Interesujące jest, w jaki sposób doszło do nakłonienia byłych radnych (przynajmniej niektórych) do swoistej degradacji polegającej na obejmowaniu niższych urzędów, skoro z reguły były one obsadzane przez samych mieszczan. Najbardziej prawdopodobny wydaje się scenariusz zakładający daleko idąca ingerencję administracji właściciela, której motywy na obecnym etapie badań są trudne do rozpoznania. Faktem jest, że dzięki temu określenie kręgu elity władzy w takim mieście jak Przecław czy Radomyśl jest w końcu XVIII w. poważnie utrudnione.

Liczebność kręgu osób, które należały do elity władzy, determinowały takie czynniki jak wielkość rady urzędującej, częstotliwość rotacji na urzędzie, a także śmiertelność. Co do pierwszego z nich wiemy, że kształtował się różnie, nie tylko w zależności od miasta, ale także w przekroju chronologicznym. Utrudnia to wzajemne porównania, stąd niezbędne jest posłużenie się wskaźnikiem ruchomym obrazującym stabilność składu rady miejskiej niezależnie od jej wielkości, obliczanym według następującego wzoru: S.r.=(x-r.min.)/(r.max.-r.min.), gdzie rezultat równy 0 oznacza, że $\mathrm{w}$ danym okresie była ona obsadzana przez minimalną liczbę osób potrzebną do skompletowania pełnego składu, a 1 oznacza, że w każdym roku skład całkowicie się zmieniał ${ }^{65}$.

${ }_{64}$ Połączone rady (urzędująca i stara) rozpatrywały zarzuty wobec miejscowego landwójta; ANK, rkps dep. 463, s. 124. Starzy rajcy są wspomniani także w Bobowej w 1663 r. (ANK, HGZ 96, s. 573) czy Radomyślu w 1678 r. (ЦДІАУЛ, f. 40, op. 1, spr. 7, s. 74). W opisanym wyżej charakterze w połowie XVI w. działała stara rada prywatnego miasteczka Kamionka w ziemi lubelskiej; M. Kordas, dz. cyt., s. 224.

${ }^{65}$ We wzorze $x$ oznacza rzeczywistą liczbę osób zasiadających $\mathrm{w}$ radzie $\mathrm{w}$ danym okresie, r.min. najmniejszą możliwą teoretycznie liczbę radnych w tym czasie, natomiast r.max. największą teoretycznie liczbę radnych w wybranym przedziale czasu. 
Tabela 1. Wskaźniki stabilności składu rad miejskich miast małopolskich w XVII- XVIII w.

\begin{tabular}{|c|c|c|c|c|}
\hline Okres & Wskaźnik & $\begin{array}{c}\text { Minimalna } \\
\text { liczba } \\
\text { radnych }\end{array}$ & $\begin{array}{c}\text { Maksymalna } \\
\text { liczba } \\
\text { radnych }\end{array}$ & $\begin{array}{c}\text { Rzeczywista } \\
\text { liczba } \\
\text { radnych }\end{array}$ \\
\hline \multicolumn{5}{|c|}{ Nowy Wiśnicz } \\
\hline $1713-1725$ & 0,31 & 4 & 40 & 15 \\
\hline $1726-1736$ & 0,33 & 4 & 40 & 16 \\
\hline \multicolumn{5}{|c|}{ Zakliczyn } \\
\hline $1731-1740$ & 0,49 & 4 & 40 & 24 \\
\hline $1737-1745$ & 0,39 & 4 & 40 & 18 \\
\hline $1743-1753$ & 0,44 & 4 & 40 & 20 \\
\hline \multicolumn{5}{|c|}{ Lęczna } \\
\hline 1726-1735 & 0,50 & 4 & 40 & 22 \\
\hline $1736-1745$ & 0,44 & 4 & 40 & 20 \\
\hline $1746-1755$ & 0,25 & 4 & 40 & 13 \\
\hline 1756-1765 & 0,47 & 4 & 40 & 21 \\
\hline $1766-1775$ & 0,56 & 4 & 40 & 24 \\
\hline $1776-1784$ & 0,58 & 5 & 41 & 26 \\
\hline \multicolumn{5}{|c|}{ Przecław } \\
\hline $1680-1683$ & 0,50 & 4 & 16 & 10 \\
\hline 1776-1779 & 1,00 & 2 & 8 & 8 \\
\hline 1783-1785 & 1,00 & 4 & 12 & 12 \\
\hline $1776-1785$ & 0,88 & 4 & 20 & 18 \\
\hline
\end{tabular}

Źródło: oprac. własne na podstawie: ANK, rkps dep. 160, 424, 452, 463; J. Łosowski, Urzędnicy miejscy, cechowi, braccy i szpitalni Łęcznej do r. 1810. Spisy, Łęczna 2004, s. 65-72.

Z powyższej - dość przypadkowej - próby trudno wyciagać generalne wnioski. Wydaje się jednak, że ranga gospodarcza i demograficzna miasta miała wpływ na kreowanie elit. W stosunkowo ludnym i zamożnym Wiśniczu skład rady zmieniał się rzadziej niż w pozostałych miastach, a na przeciwnym biegunie leży niewielki Przecław. Dane dla tego miasteczka sa wprawdzie szczątkowe i obejmują krótkie okresy, ale wskazuja na częstą wymianę rajców, zwłaszcza w okresie porozbiorowym, kiedy w badanych przedziałach każdego roku występował właściwie inny zespół urzędników. Tym samym w dekadzie 1776-1785, dla której mamy wiadomości z siedmiu lat, w radzie znalazło się aż 18 mieszczan. Był to skutek kooptacji na urzędy z szerokiego grona obywateli, praktykowanej przez właścicieli miast prywatnych. Opisy elekcji władz 
miejskich w Radomyślu z przełomu lat 80. i 90. XVIII w. jako istotna kwalifikację do objęcia po raz pierwszy urzędu podaja fakt posiadania miejskiej nieruchomości i niepełnienia dotąd żadnej funkcji ${ }^{66}$.

\section{Elita majątkowa}

Możliwości wzbogacenia się członków elity władzy w miastach prywatnych wydaja się mniejsze niż w ośrodkach królewskich. Liczne wzmianki w ordynacjach właścicielskich ostrzegajace przed korupcja. uprzywilejowaniem rodzin w wybieranych podatkach (Mielec, Zakliczyn) sugeruja, że zwierzchność dworska była w tym względzie czujna. Gdy w Radomyślu (Wielkim) w 1653 r. o nadużycia przy zbieraniu podatków i składek posądzono rajcę Andrzeja Ujskiego, na skargi mieszczan zareagował ówczesny dzierżawca majątku Mierzejowski, nakazując „tak dochodów, jako i rozchodów aby P. Ujski pokazał z kogo co wziął i kędy i na co wydał [...] nakazał mu JM decretem, aby przysięga te regestra potwierdził...”67.

Źródła zamożności mieszczan szlacheckich płynęły zatem z innych zajęć. Wydaje się, że najbardziej dochodowymi zajęciami miejskimi były handel hurtowy i produkcja alkoholu - oba zresztą w odniesieniu do chrześcijan coraz rzadszymi. Niemniej jednak postawienie znaku równości, szczególnie w XVIII stuleciu, między browarnikami i gorzelnikami, najbogatszymi mieszczanami i najbardziej wpływowymi członkami elity władzy nie jest zbyt dużym uproszczeniem ${ }^{68}$.

Były jednak przecież takie miasta prywatne, gdzie takich możliwości zarobkowania - z uwagi na konkurencję ludności żydowskiej - niemal nie było. Niewiele da się wprawdzie powiedzieć o sposobach zarobkowania elity władzy w Przecławiu poza końcem XVIII w., ale jak pamiętamy, z uwagi na szeroko zakrojone powoływanie tamtejszych mieszczan na urzędy trudniej zdefiniować rzeczywistą elitę

${ }^{66}$ W 1790 r. na pisarza miejskiego radomyskiego wybrano Szymona Chałupskiego, „który w mieście dom posiada, a żadnej dotąd w obywatelstwie nie czynił posługi aby równie tę urzędowna podległość uczuł, która każdego w szczególności dosięgnąć powinna”, niemal identycznie motywowano rok wcześniej wybór jego poprzednika; ЦДІАУЛ, f. 40, op. 1, spr. 10, s. 224, 227.

${ }_{67}$ Tamże, spr. 6, s. 70.

68 Tak wyglądało to w Nowym Wiśniczu, gdzie w 1712 r. właściciele dwóch browarów - Jan Knorowic oraz Piotr Rogożowic - posiadali również po kilka miejskich nieruchomości, a także zajmowali stanowiska radnych; ANK, rkps IT 2046, s. 272-277; rkps dep. 160, s. 3, 85. 
urzędniczą. Nic też dziwnego, że wśród tamtejszych radnych (burmistrzów) z przełomu lat 70. i 80. XVIII w. dosyć wiernie odwzorowana jest zawodowa struktura ogółu mieszczan. Pewnym odstępstwem jest jedynie nieproporcjonalnie wysoka reprezentacja krawców, w dodatku jeden z nich - Andrzej Szeglowski - był rok w radzie i przez 6 lat landwójtem. Raczej niewielkim uczestnictwem we władzach miejskich legitymowali się przecławscy kupcy trzody chlewnej, pewnie z przyczyn obiektywnych, chociaż to właśnie oni należeli przypuszczalnie do najzamożniejszych.

To prowadzi nas do kwestii mieszczan zamożnych, ale bez dostępu do lokalnego establishmentu urzędniczego. Na istnienie takich sytuacji wskazują osoby Józefa Milejowicza i Józefa Skórskiego, niewątpliwie zamożnych przecławskich handlarzy wieprzami, którzy zawarli między sobac w 1760 r. transakcję sprzedaży domu w rynku przecławskim (ze spichlerzem i sadem) na kwotę 1710 złp. Milejowicz był również właścicielem największego gospodarstwa rolnego ${ }^{69}$, a w 1758 r. razem z żoną ufundował dla miasta księgę miejską oprawioną w skórę ze złoceniami. Był ławnikiem, ale nic nie wiadomo o pełnionych przez obu wyżej wymienionych ważniejszych stanowiskach ${ }^{70}$.

\section{Podsumowanie}

W świetle zaprezentowanych ustaleń można stwierdzić, że formowanie się elity władzy w małych miastach prywatnych było trudniejsze niż w zbliżonych wielkościa ośrodkach królewskich, ale nie niemożliwe. W każdym razie trzeba unikać w tym względzie automatyzmu, zakładając, że np. każdego członka rady miejskiej można zaliczyć w skład lokalnej elity lub nawet samej elity władzy. Piastujący najwyższe godności miejskie znajdowali się $\mathrm{w}$ omawianych ośrodkach z jednej strony pod presją właściciela, który bądź przez własne ustawodawstwo, bądź przez decyzje personalne kształtował zakres ich autonomii. Z drugiej strony znacząca była rola ogółu obywateli, czyli pospólstwa, które nie miało znaczącego wpływu na formowanie elity urzędniczej, ale współuczestniczyło w procesie tworzenia lokalnego prawa i kontroli władzy.

${ }^{69}$ Istnieją poszlaki, że inni najwięksi miejscowi „rolnicy” również byli kupcami: gospodarstwo 4,8 ha (6 co do wielkości) posiadał Stanisław Sałacki, a gospodarstwo 3,7 ha (8 co do wielkości) Józef Skórski - obaj handlarze świń. Najzasobniejszy w grunty znany rzemieślnik to Stanisław Ciernia, kuśnierz, posiadający 3,2 ha.

${ }^{70}$ ANK, rkps dep. 450, s. 1, 88; jest to właśnie księga ufundowana przez Milejowicza. 
Warto zasygnalizować symptomy pewnych zmian instytucjonalnych samorządu miejskiego. Teoretycznie wszystkie ośrodki obdarowane przywilejem prawa magdeburskiego funkcjonowały w niewiele zmienionym modelu niezależnie od sytuacji własnościowej. Niemniej jednak w mniejszych ośrodkach prywatnych, mimo powierzchownego naśladownictwa miast królewskich (nomenklatura urzędników), zaczęła się kształtować inna hierarchia miejskich urzędów, a rola rady relatywnie malała.

Mimo wszystko nie można uznać społeczności małomiasteczkowych w obrębie dóbr prywatnych za całkowicie egalitarne. Bycie członkiem elity tych społeczności wiązało się z częstym obejmowaniem urzędów miejskich, zgodnie z przyjętą hierarchią oraz wysokim statusem majątkowym. Zapewne w większości przypadków między tymi elementami występowała koniunkcja, ale znane sa przypadki osób niewątpliwe zamożnych nieaspirujacych do sprawowania wysokich urzędów.

Powyższe rozważania nie zamykaja możliwości badania dalszych problemów szczegółowych. Do istotniejszych trzeba zaliczyć kwestię, na ile odnotowane odmienności ustrojowe miast prywatnych względem pierwotnego magdeburskiego modelu kształtowały się wspólnie, a na ile miały charakter indywidualny i przypadkowy. Ponadto istotne wydaje się też bliższe przyjrzenie się, w jaki sposób na oddalanie się od wzorca ustrojowego reprezentowanego przez miasta królewskie wpływała wielkość i pozycja ekonomiczna ośrodka prywatnego.

\section{Bibliografia}

Bartoszewicz A., Warta. Społeczeństwo miasta $w$ II połowie XV i na poczatku XVI wieku, Warszawa [1997].

Bogucka M., Miasto - spoteczność, w: Encyklopedia historii gospodarczej Polski do 1945 roku, t. 1, red. A. Mączak, Warszawa 1981, s. 521-525.

Bogucka M., Samsonowicz H., Dzieje miast i mieszczaństwa $w$ Polsce przedrozbiorowej, Wrocław 1986.

Codello A., Zbiegostwo mieszczan rzeszowskich w pierwszej połowie XVIII w., „Małopolskie Studia Historyczne” 1, 1958, z. 1, s. 17-28.

Czaja R., Spoteczna mobilność jako paradygmat badań nad patrycjatem i grupami kierowniczymi w średniowieczu, w: Elita władzy miasta Krakowa i jej zwiazki $z$ miastami Europy w średniowieczu i epoce nowożytnej (do połowy XVII wieku). Zbiór studiów, red. Z Noga, Kraków 2011, s. 9-21.

Ćwik W., Miasta królewskie Lubelszczyzny w drugiej połowie XVIII wieku, Lublin 1968.

Horn M., Sktad zawodowy magistratu przeworskiego latach 1600-1650 na tle struktury zawodowej i spolecznej miasta, PH, t. 60, 1969, z. 2, s. 270-290. 
Kordas M., Z badań nad elitami małomiasteczkowymi w Polsce XV-XVI wieku (Rajcy i ławnicy miasta Kamionki w ziemi lubelskiej), „Średniowiecze Polskie i Powszechne" 3 (7), 2011, s. 205-226.

Leśniak F., Krosno w czasach Odrodzenia. Studia nad społeczeństwem miasta, Kraków 1992.

Leśniak F., Miasto w latach 1565-1772, w: Limanowa. Dzieje miasta, t. 1, red. F. Kiryk, Kraków 1999, s. 69-209.

Łosowski J., Urzędnicy miejscy, cechowi, braccy $i$ szpitalni Łęcznej do r. 1810. Spisy, Łęczna 2004.

Mazek D., Ku ozdobie i profitowi. Prawodawstwo miast prywatnych Wielkopolski 1660-1764, Warszawa 2003.

Mączak A., Rzadzacy $i$ rzqdzeni. Wtadza i społeczeństwo w Europie wczesnonowożytnej, Warszawa 1986.

Motylewicz J., Miasta ziemi przemyskiej i sanockiej $w$ drugiej połowie XVII i XVIII wieku, Przemyśl 1993.

Motylewicz J., Społeczeństwo Przemyśla w XVI i XVII wieku, Rzeszów 2005.

Noga Z., Krakowska rada miejska w XVI wieku. Studium o elicie władzy, Kraków 2003.

Opas T., Z badań nad zagadnieniem umacniania się zasady wolności osobistej mieszczan miast prywatnych $w$ Polsce XVIII wieku, w: Ustrój i prawo $w$ przeszłości dalszej $i$ bliższej. Studia historyczne o prawie dedykowane prof. Stanisławowi Grodziskiemu w pięćdziesiata rocznice pracy naukowej, red. J. Malec, W. Uruszczak, Kraków 2001, s. 145-157.

Opas T., Z badań nad zagadnieniem wolności osobistej mieszczan miast prywatnych $w$ Polsce XVII i XVIII wieku, CPH, t. 35, 1983, z. 1, s. 59-95.

Pezda J., Prokop P., Mielec $i$ okolice $w$ połowie XVI wieku, „Rocznik Mielecki" 2, 1999, s. 116-138.

Ptaśnik J., Miasta i mieszczaństwo w dawnej Polsce, Warszawa 1949.

Samsonowicz H., Elita władzy $w$ matych miastach Polski w późnym średniowieczu, w: Genealogia - kregi zawodowe i grupy interesu w Polsce średniowiecznej na tle porównawczym, red. J. Wroniszewski, Toruń 1989, s. $145-159$.

Szczygieł R., Powstanie miasta Łęcznej i jego rozwój do końca XVI w., w: Eęczna. Studia z dziejów miasta, red. E. Horoch, Łęczna 1989, s. 31-53.

Średzińska A., Pozycja mieszczan $w$ miastach prywatnych ziemi drohickiej $i$ mielnickiej $w$ XVI-XVIII wieku, w: Miasta polskie w średniowieczu i czasach nowożytnych, red. P. Gołdyn, Kraków 2008, s. 281-297.

Wróbel S., Tarnów w XVII i XVIII w., w: Tarnów. Dzieje miasta i regionu, t. 1: Czasy przedrozbiorowe, red. F. Kiryk, Z. Ruta, Tarnów 1981, s. 329-432.

Wyczański A., Uwarstwienie społeczne w Polsce w XVI wieku. Studia, Wrocław 1977.

Wyrobisz A., Rola miast prywatnych $w$ Polsce $w$ XVI $i$ XVII wieku, PH, t. 65, 1974 , z. 1 , s. 19-46. 
Piotr Miodunka

Elites in small private towns of Lesser Poland in the $17^{\text {th }}$ and the $18^{\text {th }}$ century

(Summary)

The paper aims to define the elite of small private towns situated in the area of Lesser Poland in the early modern period. It has been decided that the most important criterion for determining which people belonged to the elite is the fact of holding the highest municipal offices of councillors or the office of the judicial vogt. The political system of private towns in the period in question was shaped largely by the owners, who diminished the importance of formal municipal institutions and limited the individual liberty of burghers. It was the owner who had the right to appoint people to the most important administrative posts, which led to distortions of the traditional ways of promotion deriving from smaller royal towns, where it was first necessary to be a member of the jury to be then promoted to the town council and, finally, to the post of the judicial vogt. The analysed cases prove that a number of differences appeared in the political systems of private towns; one of them was the increase in the importance of the first juror (senior). It has also been observed that the activities of the owner caused great rotation among the town councillors, which constituted an obstacle for the formation of the power elite. Nonetheless, it is possible to indicate the people who frequently held positions in the highest municipal offices and thus can be considered a part of the elite. It can be observed that these people were also wealthy, but there have appeared examples of people enjoying high financial status and not holding any important administrative posts.

Piotr Miodunka - dr, adiunkt w Katedrze Historii Gospodarczej i Społecznej Uniwersytetu Ekonomicznego w Krakowie. Zainteresowania badawcze: demografia historyczna, historia społeczno-gospodarcza Polski od późnego średniowiecza do połowy XIX w., historia mniejszych miast, geografia historyczna. Ostatnio opublikował: L'essor de la culture de la pomme de terre dans au sud de la Pologne jusqu'au milieu du XIX ${ }^{e}$ siècle, „Histoire \& Sociétés Rurales” 42, 2014, nr 2, s. 67-84; Wybrane problemy rozwoju matych miast galicyjskich $w$ okresie przedautonomicznym (1772-1866), ,Zeszyty Naukowe UEK: Problemy Społeczne, Polityczne i Prawne” 11 (935), 2014, s. 23-43. E-mail: miodunkp@uek.krakow.pl. 